\title{
ANALYSIS ON TERMS OF TRADE OF INDONESIA'S NICKEL
}

\section{ANALISIS TERMS OF TRADE NIKEL INDONESIA}

\author{
HARTA HARYADI and BAMBANG YUNIANTO \\ $R$ \& D Centre for Mineral and Coal Technology \\ Jalan Jenderal Sudirman 623 Bandung 40211 \\ Phone (022) 6030483, Fax. (022) 6003373 \\ e-mail: harta@tekmira.esdm.go.id
}

\begin{abstract}
The import-export trade of nickel Indonesia until 2013 was always in a less prestigous position. It is due to the entire production of nickel is exported in raw materials, while nickel is continued to be imported to meet the industrial needs of stainless steel, nickel alloys, batteries and nickel metal alloys in the country. This study aims to analyze the advantages and disadvantages of export and import of nickel with a terms of trade analysis in net barter, which measures the ratio of the nickel export price with imports price, and gross barter measures the ratio of the nickel export volume to the import volume. Net barter of the analysis results shows that in 2007, the nickel export price was only 0.0121 times than the nickel import price, while gross barter indicates that the export volume was 11044.87 times compared to the import volume. Volume and value of the exports are in nickel ore), while imports in nickel oxide sinters, product of nickel metallurgy, nickel alloys, nickel waste and scrap and nickel powders and flakes. The analysis overview of nickel gives an indication that international trade (export-import) of nickel has not provided an optimal impact on the national and regional economy.
\end{abstract}

Keywords: terms of trade, nickel, nickel matte, export-import, international trade balance

\begin{abstract}
ABSTRAK
Perdagangan ekspor-impor nikel Indonesia selalu dalam posisi kurang menguntungkan sampai tahun 2013, karena seluruh produksi nikel diekspor dalam bentuk bahan mentah, sementara logam nikel terus diimpor untuk memenuhi kebutuhan industri stainless steel, nickel alloys, baterei dan logam paduan nikel di dalam negeri. Tulisan ini bertujuan untuk menganalisis keuntungan dan kerugian ekspor dan impor nikel dengan analisis Terms of Trade dalam bentuk net barter yang mengukur perbandingan harga ekspor nikel dengan harga impor, dan gross barter yang mengukur rasio volume ekspor nikel terhadap volume impor. Hasil analisis net barter menunjukkan bahwa pada tahun 2007, harga ekspor nikel Indonesia hanya 0,0121 kali harga nikel impor, sementara gross barter menunjukkan bahwa volume ekspor 11.044,87 kali dibanding volume impor. Volume dan nilai ekspor nikel Indonesia adalah dalam bentuk bijih, sedangkan impor dalam bentuk nickel oxide sinters, product of nickel metallurgy, nickel alloys, nickel waste and scrap dan nickel powders and flakes. Gambaran tentang analisis nikel memberikan indikasi bahwa perdagangan luar negeri (ekspor-impor) nikel belum memberikan dampak optimal terhadap perekonomian nasional dan regional.
\end{abstract}

Kata kunci: terms of trade, nikel, nikel matte, ekspor-impor, neraca perdagangan luar negeri

\section{INTRODUCTION}

Based on data from Geological Resource Centre (2013), Indonesia has the potential of nickel resources estimated at 2.85 billion tons (ore) and 42.21 million tons (metal); reserves potential of 1.18 billion tons (ore) and 21.43 million tons (metal) with an average of nickel content $1.20 \%-3.25 \%$. Nickel ore reserves in Indonesia are classified in proven reserves and inferred, whereas nickel ore resources are classified to the hypothetical, indicated and measured resources. Most of nickel resources and reserves have been mined 
and exported in nickel ore by enterprises that have been emerged in the last decade. Most other nickel ore are exported in the processed materials such as nickel matte (PT. Vale Indonesia) and ferronickel (PT. Aneka Tambang/Antam Tbk.). Type of the deposit of nickel is divided into two grades, the low grade ore, limonitic types with low content of $\mathrm{Ni}$ : 1.4 to $1.7 \%$, as well as its Co content is relatively high (0.008 to $0.12 \%)$ and high iron. This type is usually found in the top layer of soil; and high grade nickel ore types saprolitic/garnertitic with $\mathrm{Ni}$ content: 1.8-2.7\%, Co: 0.03 to $0.08 \%$ and low iron levels. Meanwhile, Indonesia has nickel laterite reserve, which is identified around 576.90 million tons with total nickel content as much as 13.20 million tons. This makes Indonesia as the world's third largest sources of laterite nickel after New Caledonia and the Philippines. Distribution area of the lateritic nickel deposits is in Sulawesi, Moluccas, Kalimantan and Papua.

There are two large-scale nickel mining companies operate operating in Indonesia up to now, namely PT. Antam Tbk. and PT. Vale Indonesia. It is not only these two companies, but also there are hundreds of nickel mining companies that mainly operate in Southeast Sulawesi, among others PT. Makongga Putra Sejahtera, PT. Pernik Southeast Sulawesi, PT. Cahaya Modern Metalindo, PT. Macika Mada Madana, PT. Pernik, PT. Sambas Mineral Mining, PT. Macika Mineral Industries, PT. Wijaya Nickel Nusantara, PT. Sumber Setia Budi, PT. Dharma Bumi Kolaka (Southeast Sulawesi Mining Office, 2013). PT Antam Tbk. produces two types of nickel, namely nickel ore and ferronickel, while PT. Vale Indonesia manufactures converter matte and $\mathrm{Ni}+\mathrm{Co}$ in matte. Most of the nickel production is exported to Japan, Australia and the Netherlands, while small mine companies export nickel ore to China.

The resources and reserves of Indonesia nickel are widely distributed in East Kaliman$\tan$ (Gn Nuih), Central Sulawesi, South Sulawesi, Southeast Sulawesi, North Moluccas, West Papua, and Papua. A large enough reserves are possible in the working area of PT. Antam Tbk. as well as in the working area of PT. Vale Indonesia. It is sufficient to support the activities of the both companies for next several decades (Table 1).
The current condition of Indonesian nickel import-export trade does not provide significant benefits for the national economy up to now, although Indonesia has extremely large nickel resources. This is due to the entire production of nickel produced is sold in raw material, in particular to China and Japan, while Indonesia imports nickel metal from Australia to meet the steel smelting industry at higher prices than export prices.

In 2007, the imports rate of Indonesian nickel metal reached 625.40 tons at a price of US\$ 17,229.00 per ton. In 2012, the imports were recorded 518.70 tons at a price of US\$ $15,722.00$ per ton. Perhaps, the imports are a processed nickel ore, which was exported from Indonesia. In 2007, crude nickel exports reached 6.91 million tonnes at a price of only US $\$ 200.45$ per ton, while in 2012, its exports reached 48.62 million tons at a price of US $\$ 64.00$ per ton. Viewing from the exports volume, it was seen that during 2007-2012, the nickel trade obtained surplus values. However, it has not given an overview regarding competitiveness of real national nickel processing industry.

Durability and competitiveness of the local industries is very low compared to other countries and this makes industry national economy suffers a financial loss, because of its added value is much smaller than other countries, which process them into a wide range of nickel products, and then they are imported by Indonesia. It is understandable, if Indonesia loses foreign exchange and large nickel resource at the same time.

According to data from the Directorate General of Mineral and Coal Mining (2013a), during the period of 2007-2012, the nickel export tends to rise. As comparison, in 2003, the exports reached 6.91 million tons, and in 2012 the export volume reached 48.62 million tons (Table 2).

During 2007-2012, seen from the price, the net barter analysis the nickel $<1$, so it is estimated to obtain to high grades of nickelbased commodity import than export value. To overcome the negative net export of nickel-based commodities, it is necessary more strategic steps in order to prepare the construction of a nickel smelter in Indonesia as soon as possible, so it could create valueadded production of national nickel much higher than before. 


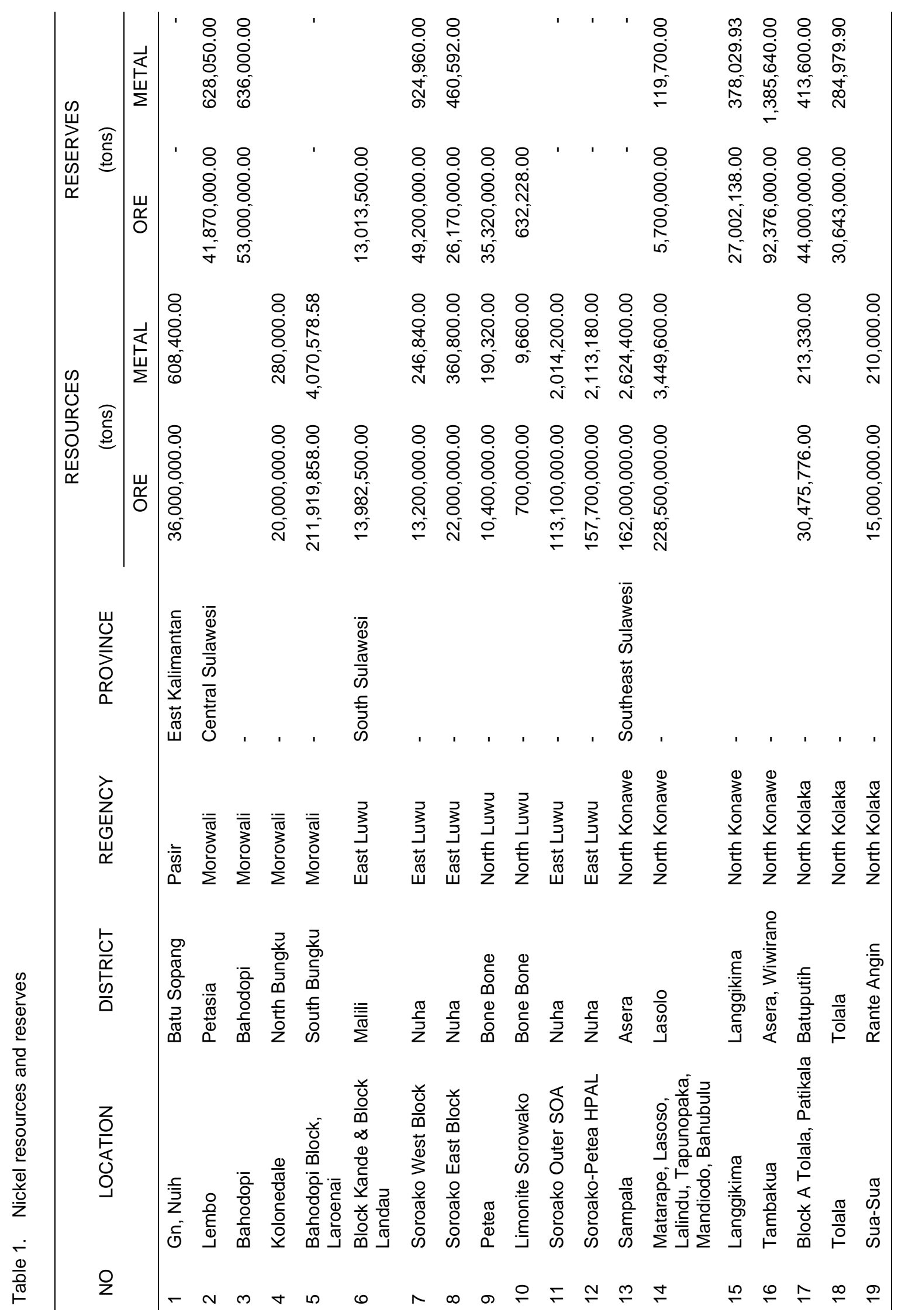


INDONESIAN MINING JOURNAL Vol. 19, No. 1, February $2016: 51$ - 64

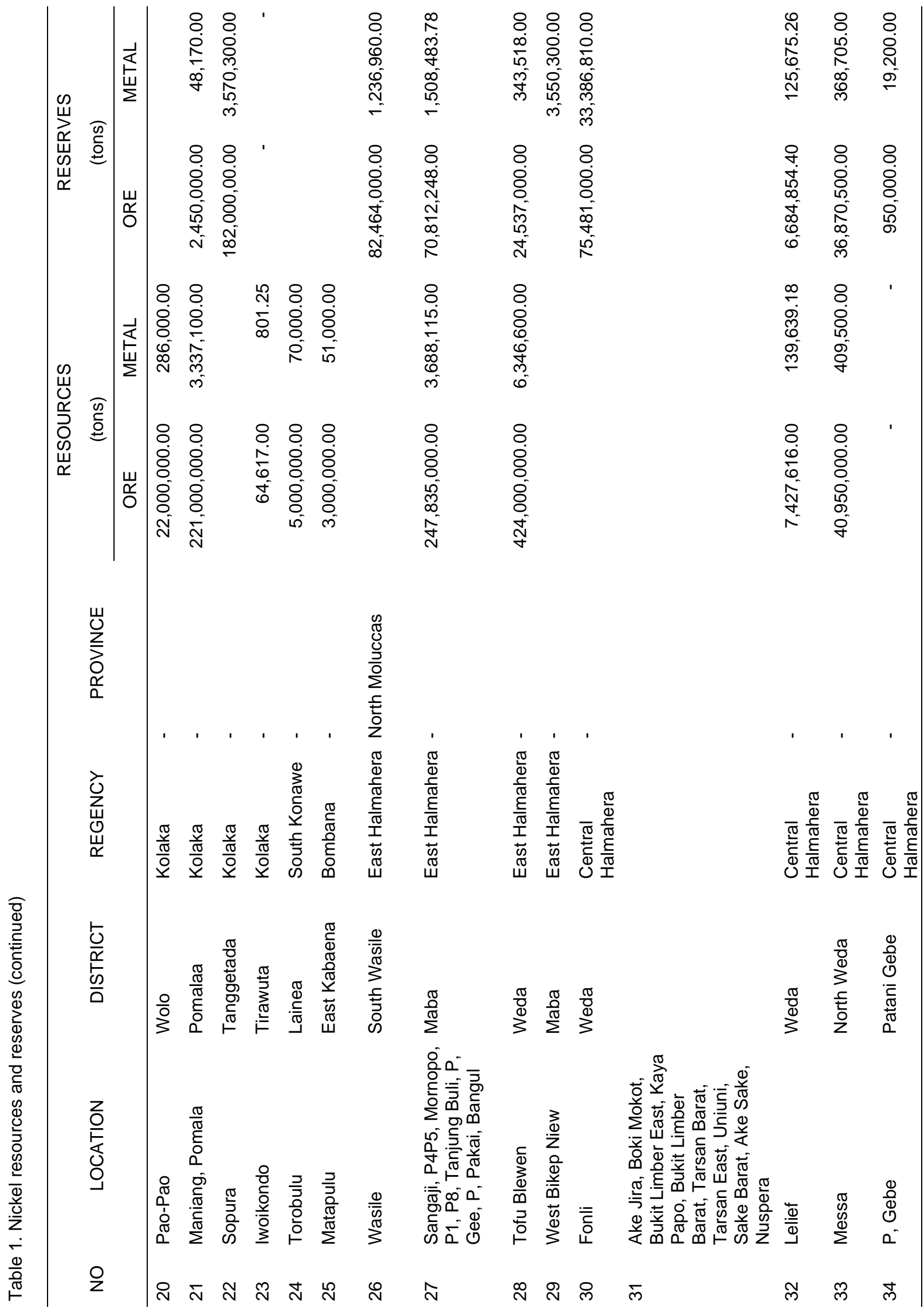




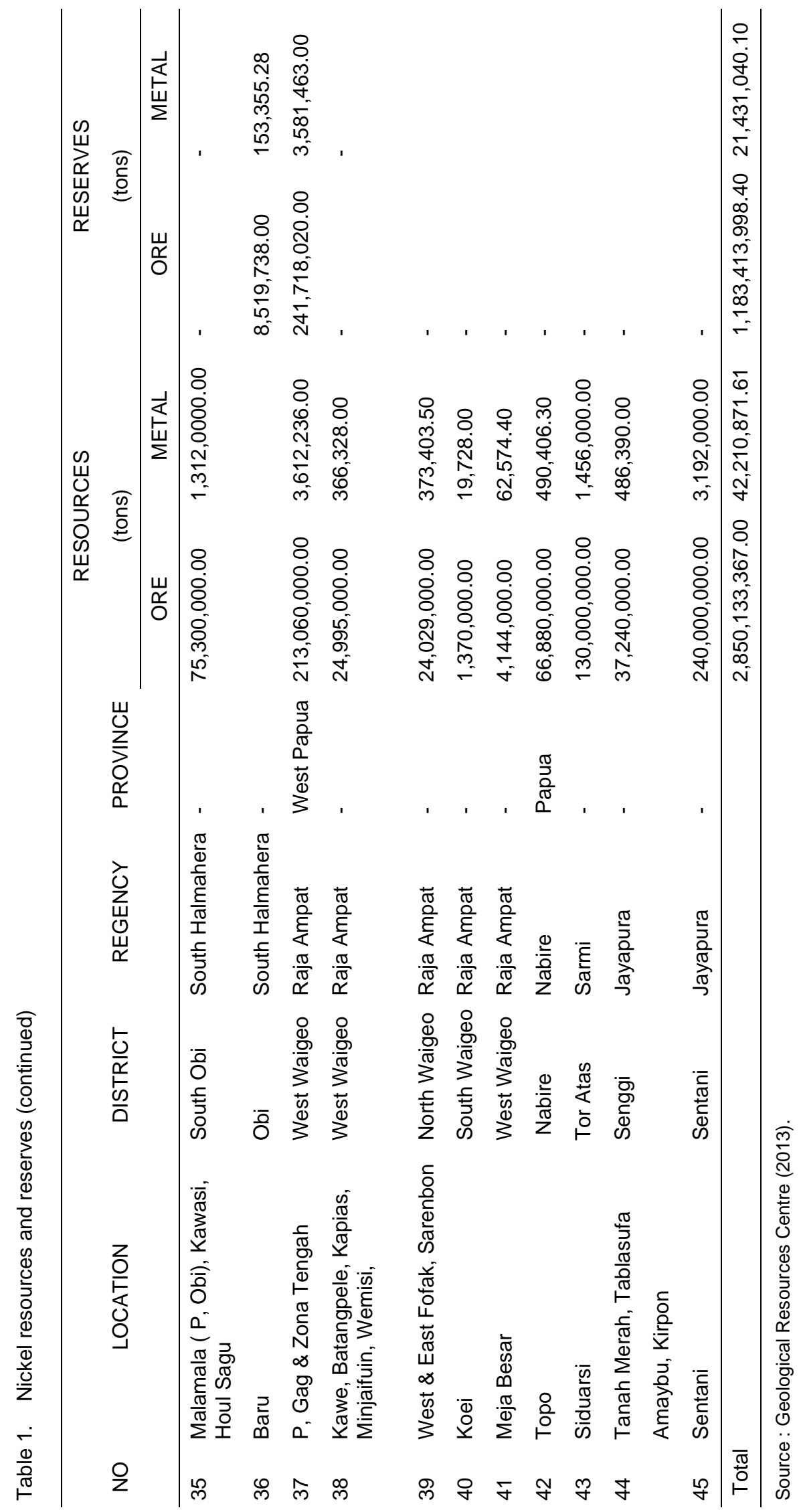


The nickel price is extremely determined by the international market. Some of the dominant factors affecting the price is the rise and fall of demand for the metal processing plant nickel (stainless steel and nickel alloy). In 2007, the price of nickel ore was recorded at US\$208.45 per ton, while nickel metal reached US\$17,229.00 per ton (Directorate General of Mineral and Coal, 2014b). In 2013, the nickel prices declined into US\$26.01 per ton and nickel metal to US\$22,890.29 per ton (Table 2).

International trade is basically the exchange of goods and services. Every country has different resources, if the goods or services needed are not available or insufficient in the country, so the goods are going to be imported, and vice-versa.

Import and export activities are implemented by each country in the world. This shows that international trade is increasingly important for every country. There are several factors that encourage international trade, among others, desire of country to conduct trade with other nations. It was aimed to meet the needs of its national industrial raw materials have not been able to be fulfilled from the manufacturer of the country (Ministry of Industry, 2013). International trade was also carried out due to an excessive production of goods in the country pushing to sell surplus products abroad, while imports were carried out to meet national demands, because not all the necessary goods of a country can be fulfilled with products in the country. To meet the needs, it can be overcome by importing from other countries. It is due to Indonesia has not been able to produce nickel metal, so as to meet the needs of the industry, such goods must be imported (Tulus and Simon, 2004).

The various kinds of the production condition is based on the potential of production factors owned by a state. For example, Indonesia has a great potential in producing nickel ore. Through international trade, Indonesia can obtain goods that cannot be produced in the country for fulfilling its industrial needs. During this time, Indonesia exported nickel ore to Japan and China. However, in other side, Indonesia required their production of nickel metal. Japan and China will gain advantages from this trade, while Indonesia also obtain benefit to fulfill its domestic industry from imports due to there is no nickel metal processing plant (Sugiarto and
Herlambang, 2006). In addition, an international trade allows a country to learn more efficient production techniques and more modern management methods of importing countries (Kennedy, 2013).

Due to the international trade, the country which is concerned to that trade will obtained benefit from specialization. Eventhough, a country can produce the same goods as those produced by other countries, but sometimes the country is better to import goods from abroad. For example, China and Japan have the ability to produce nickel metal, but Japan can produce it more efficient than China. For efficiency reasons of using factors of production in these circumstances, Japan should reduce its nickel metal production and import goods from China. By conducting specialization and trade, each country can obtain advantages, that factors of production of each country can be used more efficient and any country can use more goods aside from being produced domestically (Krugman et al., 2008).

There are differences in production costs of international trade, which aims to produce certain goods between one country to other countries (Pujoalwanto, 2014). Employers sometimes do not operate the engines (its production means) maximally. It is due to surplus production occured was feared unable to be absorbed by the market because of prices decline. One of the international trade advantages is selling excessive product to abroad by expanding export markets (Khan et al., 2012).

International trade is also affected by factors of a country's need of foreign exchange. In meeting their needs, every country should have the foreign exchange reserves used in doing construction. One source of revenues is the revenue of international trade or export sales (Bank Indonesia, 2013). International trade is also the interest of gaining advantages (foreign exchange) to increase visible state revenue, through its export-import activities (Ministry of Finance, 2014).

According to Poerwadarminta (2015), the definition of export is the delivery of merchandise abroad and it is an important benchmark to determine how much economic growth in a country. The merchandise can be physical goods or services. From this activity, 
business in the real sector will be more assured. Therefore, export in the long term can be "a hero" in foreign exchange for national economic growth.

Each country is never apart from export and import activities. Those activities are based on the condition of every country which has different characteristics to another country. To complement and fill the gap of these characteristics, import-export activities are carried out as import-export of Indonesia nickel commodities. Indirectly, the export and import of nickel commodities have significant contribution in boosting economic growth in Indonesia. Based on data taken from the Ministry of Commerce of the Republic of Indonesia, exports and imports are also the economic indicators of Indonesia. Indonesia is a rich country in nickel resources. However, the condition of Indonesia's foreign trade always got deficit until now due to Indonesia's import value is more dominant than its exports value (Batubara, 2015).

Indonesia has large dependence on international trade as the national economy booster. According to Yuliardi (2008), capital flow is one of economic activity that cannot be separated from international trade, both incoming and outgoing of a country. When an international trading in terms of export and import activities, it is possible to do production factor movement from exporter to importer due to there is a difference of cost in international trade.

Pramudita (2012) also stated that a country should not only expects to international trade in general, especially exports as the sole booster of economic growth today. Indonesia trade performance today is getting decrease, it is due to the conditions of trade balance (deficit) from year to year. It shows that benefit cannot always be gained from trading activities, so the government must begin to think of other alternatives in order to solve its deficit. According to Antoni (2008), attracting foreign investors to invest in Indonesia in Foreign Direct Investment (FDI is one of ways that the government can do. FDI provides long-term positive impact on exports, while it gives negative impact on exports in the short term. However, FDI has a positive impact on imports although it not significant in statistic (Safitriani, 2014).
Prasetiawati (2012) stated that foreign investment in Indonesia is more dominant lead to the domestic market, it is not exportoriented. It impacts to the structural gap of export and import Indonesia. It means that, there is still a tendency of foreign investors invest their capital in the industry or domestic consumption sector, but not to export commodity. Then, it leads to imbalances to exports and imports numbers of Indonesia, finally the trade balancing of Indonesia is getting deficit. The most important things according to Hanna:2012 that need to be considered by the government in the export and import of nickel commodities is the continuity of trade transactions are highly dependent on the underlying regulations. If the regulations are changed frequently, it can lead to misunderstandings and mistakes of both parties, employers in the nation and abroad in nickel commodity sector. It is required an adequate explanation of the change background and its objectives, so that each party will understand and realize the rules of the game in future transactions, then it provides benefit to both the employers and the state.

To identify the international trade problems of the nickel, a term of trade (TOT) analysis is carried out by comparing the export price of nickel that its import. If the export price of nickel rises, but import price declines, thus the analysis obtains to have benefit (surplus). Otherwise, if the export price declines, while the import price rises, the analysis is indicates to suffer a financial loss (deficit). In addition, it is also calculated the ratio of the export volume to the import volume. If the export volume of nickel rises and import one declines, the analysis indicates to obtain benefit (surplus). Otherwise, if the export volume decreases, while the import volume increases, the analysis indicates loss (deficit).

The aims of the TOT analysis is to identify how large the benefits and disadvantages of international trading conditions of the nickel, and all stakeholders can identify less optimal nickel sector in its international trade (export-import), so its role in improving the local economy and the nation has not been optimal yet. 


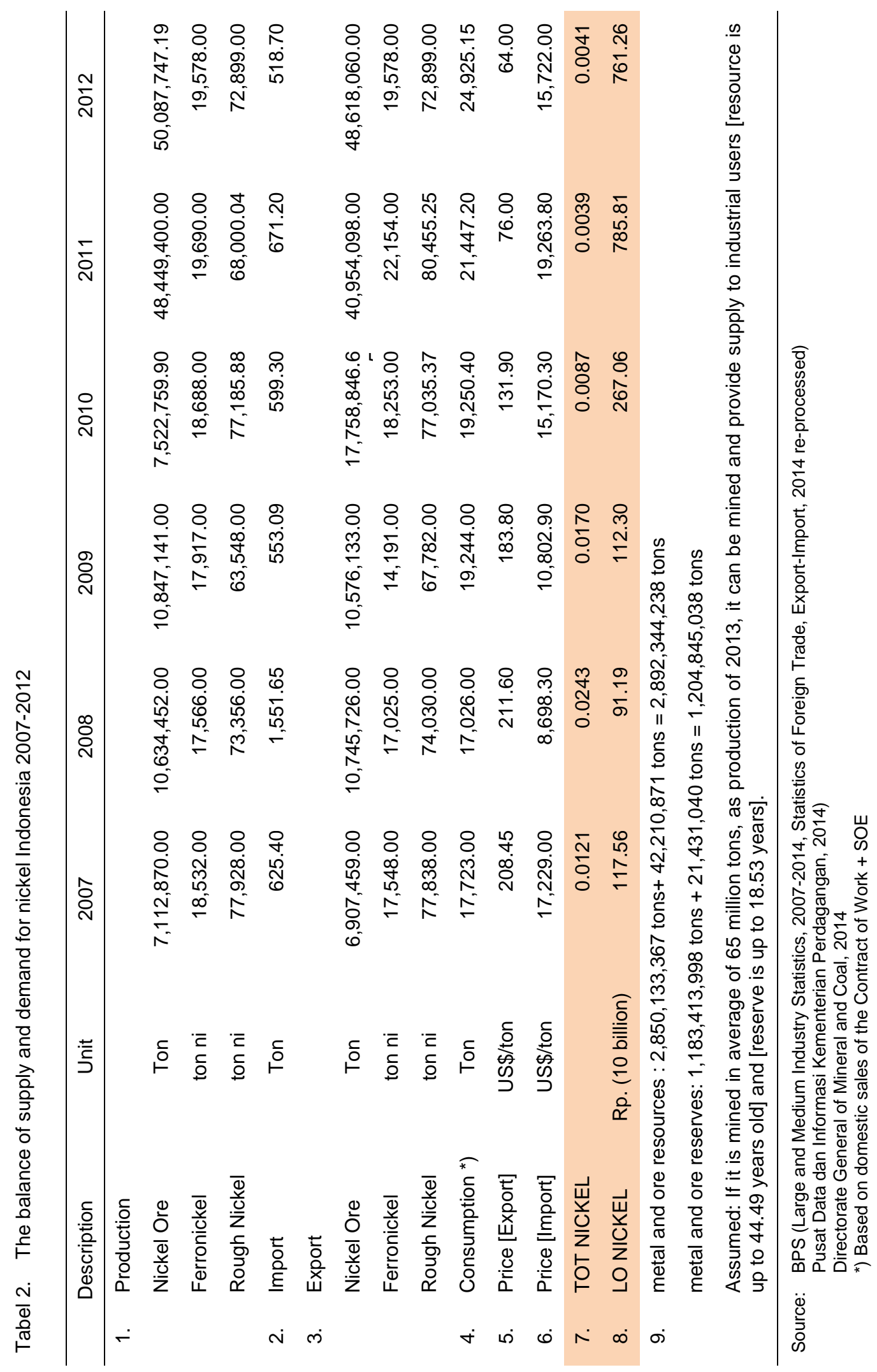




\section{METHODOLOGY}

\section{Types and Data Collection Techniques}

The analysis was conducted by using quantitative and qualitative methods. Using the quantitative methods means to obtain this type of data in general overview of the export data, export price, export value, import data, import prices, and import value. Export and import data are secondary data obtained through library or directly from agencies associated with the mining sector. Using qualitative methods means to determine the real condition of nickel export and import, to conduct a direct review to several nickel producers located in Southeast Sulawesi, namely PT. Makongga Putra Sejahtera, PT. Pernik Sulawesi Tenggara, PT. Cahaya Modern Metalindo, PT. Macika Mada Madana, PT. Jangkar, PT. Sambas Mineral Mining, PT. Macika Mineral Industries, PT. Wijaya Nickel Nusantara, PT. Sumber Setia Budi and PT. Dharma Bumi Kolaka.

\section{Calculation Method of TOT}

The state's obligation is to ensure the availability of raw materials, energy, capital and guidance to domestic industries. The state is also obliged to manage the export and import of commodities, so it can really provide benefits to the domestic industry and a positive influence on the national economy (Ratya and Michael, 2009).

Of the nickel import-export trade carried out by Indonesian, TOT is calculated to identify how much benefits and disadvantages of nickel international trade conditions implemented by using the following equation (Amir, 2004).

To calculate the ratio of export prices to import prices of nickel (net barter of TOT), it is formulated by using the following equation:

$$
\mathrm{Tc}(\mathrm{N})=\frac{\mathrm{Px} 1 / \mathrm{P} \times 0}{\mathrm{Pm} 1 / \mathrm{Pm} 0}
$$

Tc = TOT of commodity (net barter of TOT);

$P=$ price index

$X=$ export price

$M=$ import price

1 = given year

0 = basic year
Parameter measured is export price of nickel ore compared to import prices. If the export price is higher than import, the TOT is indicated to be improved, and vice versa.

As for calculating the ratio of the export volume of nickel to its import volume (gross barter of TOT), it is formulated by using the following equation:

$T c(G)=\frac{Q \times 1 / Q x 0}{Q m 1 / Q m 0}$

Tc = TOT commodity (gross barter of TOT);

$\mathrm{Q}=$ volume index

$\mathrm{X}=$ export volume

$M=$ import volume

1 = given year

0 = basic year

Parameter measured is export volume of nickel ore compared to its import volume. If the export volume of nickel ore is higher than import, the TOT is indicated to be improved, and vice versa.

\section{RESULTS AND DISCUSSION}

In 2007, the export volume of nickel identified was 6.91 million tons, the export price of nickel was US\$208.45 per ton, and the export value obtained is US\$ $1,439,859,829$. In the same year, nickel import was less than export, with a total of 625.40 tons at a price of US $\$ 17,229.00$ per ton, so the values obtained was US\$ $10,775,017$. The TOT value (for net Barter of TOT in 2007) obtained was:

$\mathrm{T} 2007=\frac{\mathrm{Px} 1 / \mathrm{Px} 0}{\mathrm{Pm} 1 / \mathrm{Pm} 0}=\frac{208,45}{17.299,00}=0,0121$

At the same year, TOT value obtained was (for gross barter of TOT in 2007):

$\mathrm{T} 2007=\frac{\mathrm{Q} \times 1 / \mathrm{Q} \times 0}{\mathrm{Qm} 1 / \mathrm{Qm0}}=\frac{6.907 .459}{625,40}=11.044,87$

In 2013 , nickel exports substantially obtained an increase into 64.80 million tons, the export price at US\$26.01 per ton, and the export value obtained was US $\$ 1,685,247,617$. In the same year, the imports was more less than export, with a total of 875.00 tons at a price of US $\$ 22,890.29$ per ton, so the values 
obtained is US\$20,029,000. The TOT values obtained was:

For net barter of TOT in 2013

$\mathrm{T} 2013=\frac{\mathrm{P} \times 1 / \mathrm{P} \times 0}{\mathrm{Pm} 1 / \mathrm{Pm0}}=\frac{26,01}{22,890 \cdot 29}=0,0011$

In 2013, TOT value obtained was (for gross barter of TOT in 2013):

$\mathrm{T} 2013=\frac{\mathrm{Q} x 1 / \mathrm{Q} \times 0}{\mathrm{Qm} 1 / \mathrm{Qm} 0}=\frac{64,802,857.00}{875.00}=74.060 .41$

The calculation of TOT analysis for nickel during 2007 and 2013 obtained:

a. In 2007, the imports rate of Indonesian nickel metal reached 625.40 tons at a price of US\$17,229.00 per ton. In 2013, the imports were recorded 875.00 tons at a price of US $\$ 22,890.0015,722.00$ per ton. Perhaps, the imports are a processed nickel ore, which was exported from Indonesia. In 2007, crude nickel exports reached 6.91 million tonnes at a price of only US \$200.45 per ton, while in 2013, its exports reached 64.80 million tons at a price of US\$26.01 64.00 per ton. Viewing from the exports volume, it was seen that during 2007-2013, the nickel trade obtained surplus values. However, it has not given an overview regarding competitiveness of real national nickel processing industry.

b. Durability and competitiveness of the local industries is very low compared to other countries and this makes industry national economy suffers a financial loss, because its added value is much smaller than other countries, which process them into a wide range of nickel products, and then they are imported by Indonesia. It is understandable, if Indonesia loses foreign exchange and large nickel resource at the same time.

c. According to data from the Directorate General of Mineral and Coal Mining (2014a), during the period of 2007-2013, the nickel export tends to rise. As comparison, in 2003, the exports reached 6.91 million tons, and in 2013 the export volume reached 64.80 million tons, (Table 2). d. During 2007-2013, seen from the price, the net barter analysis the nickel $<1$, so it is estimated to obtain to high grades of nickel-based commodity import than export value. To overcome the negative net export of nickel-based commodities, it is necessary more strategic steps in order to prepare the construction of a nickel smelter in Indonesia as soon as possible, so it could create value-added production of national nickel much higher than before.

e. During 2007-2013, total nickel exports reached 200.36 million tons, however the export value gained during the year was only US $\$ 15.91$ billion, it is due to the very low export price that was an average of US $\$ 128.82$ per ton because of being sold in raw material.

f. Meanwhile, the import of nickel metal only reached $4,519.00$ tons with the import value was US $\$ 60,423,135$. It is due to quite high import price reaching an average of US\$14,481.05 per ton, because the imported commodities were processed materials.

g. During 2007-2013, there was a trade surplus of US $\$ 15.83$ billion (exports US $\$ 15.91$ billion - import value of US\$80.45 million). The nickel resources owned by Indonesia is very large with nickel reserves of quality export is also quite high (high grade nickel). However, it did not provide significant benefits for Indonesia's national revenue, the surplus values of trade obtained during 2007-2013 was US\$ 15.83 billion. The condition is caused by the very large number volume of nickel ore with cheapest rates and the smallest import volume of nickel metal which were very expensive.

h. The entire production was exported as raw material of nickel until the year 2013. However, in the other hand, domestic industrial users of nickel require processed raw materials (semi-finished or finished materials). The mining commodities continue to grow and develop. This raw material (nickel) import increased fluctuatively from 625.40 tons in 2007 to 875.00 tons in 2013. Eventually, it was suck a lot of foreign exchange during this period amounted to US\$ 80.45 million. In addition, these conditions reduced the 
durability and competitiveness of local industries, as well as detrimental to the country because of the value-added processing or refining of nickel taken by other countries.

i. Due to nickle sold in raw material with low price, this trading conditions in the nickel sector was very detrimental to Indonesia as a country producer of nickel and there lose many opportunities to gain benefit of these minerals. The enactment of Law. Number 4 of 2009 stresses that starting in 2014 all mining products must be sold in the processed products. So, the nickel mining sector in the future will acquire quite good TOT, as well as other benefits, namely obtaining the optimization of the good value of mine, the availability of raw materials for domestic industry (saving foreign exchange), manpower absorption (improving skills, abilities, and the provision of skilled manpower absorption), as well as the increase of state revenue (royalties and taxes).

j. Although the import volume of nickel metal was more less than the export of nickel ore, nickel metal prices were much more expensive than the nickel ore. Therefore, the issue of Indonesia's foreign exchange value was greater than the acquisition of nickel value with very large number. In 2013, nickel export reached 64.80 million tons with a value of US $\$ 1,685,247,617$, with nickel prices in 2013 was US $\$ 26.01$ per ton. While, Indonesia imported numbers of nickel metal more less than exports, which amounted to 875.00 tons with a value of US $\$ 20,029,000$, with nickel price in 2013 amounted to US $\$ 22,890.29$ per ton

The entire calculation of TOT analysis for nickel Indonesia during the period 2007 to 2013 can be seen in Table 3.

\section{CONCLUSION AND RECOMMENDATION}

\section{Conclusion}

a. The positive benefits of international trade of nickel obtaining raw materials that are not produced in the country, specializing in the production, expanding markets and profits, technology and foreign exchange transfering is very low due to nickel sold in raw form with low prices, as a result it did not give a significant impact for the state and the people of Indonesia, both economic and noneconomic.

b. The low benefits of nickel international trade can be seen from the calculation of TOT. In 2007, it was acquired Net Barter of TOT value of 0.0121 , while the Grass of barter of TOT Grass at 11.044.87. While, in 2013, it was acquired Net Barter of TOT value of 0.0011 , and the Grass Barter of TOT at $74,060.41$.

c. Although for 2007 to 2013 obtained the surplus export and import trade values of nickel US\$15.83 billion, the condition did not mean that international trade of nickel was run well. This condition was due to the enormous export volumes of nickel ore with cheapest rates and most less import volume of nickel metal because of its price was very expensive.

d. In 2007, the nickel price was US\$ 208.45 per ton. If it was processed into nickel metal, it will be sold at a price of US \$ $17,229.00$ per ton (there is an increase in the value-added of 82.65 times). In 2013, the nickel price was US \$26.01 per ton. If it was processed into nickel metal, it will be sold at a price of US $\$ 22,890.29$ per ton (there is an increase in the valueadded of 880.38 times).

Mining Law No. 4/2009 and Minister of EMR( Energy and Mineral Resources) Regulation No.1 / 2014 on Mineral and Coal Mining, have already confirmed in domestic mining products, one of which is nickel. There is no export in raw form, but it must be processed into finished goods or semifinished namely into nickel matte or nickel metal, so there is value-added that can be obtained, as well as to meet the needs of the domestic stainless steel industries.

\section{Recommendation}

a. Government endeavour to increase valueadded of nickel mines through export policy of processed nickel should be fully implemented, so there are huge profits being gained from the nickel mines in the country. Mining product of nickel Indonesia is exported in raw form, so Indonesia did not get value-added or profits from nickel mine production. 


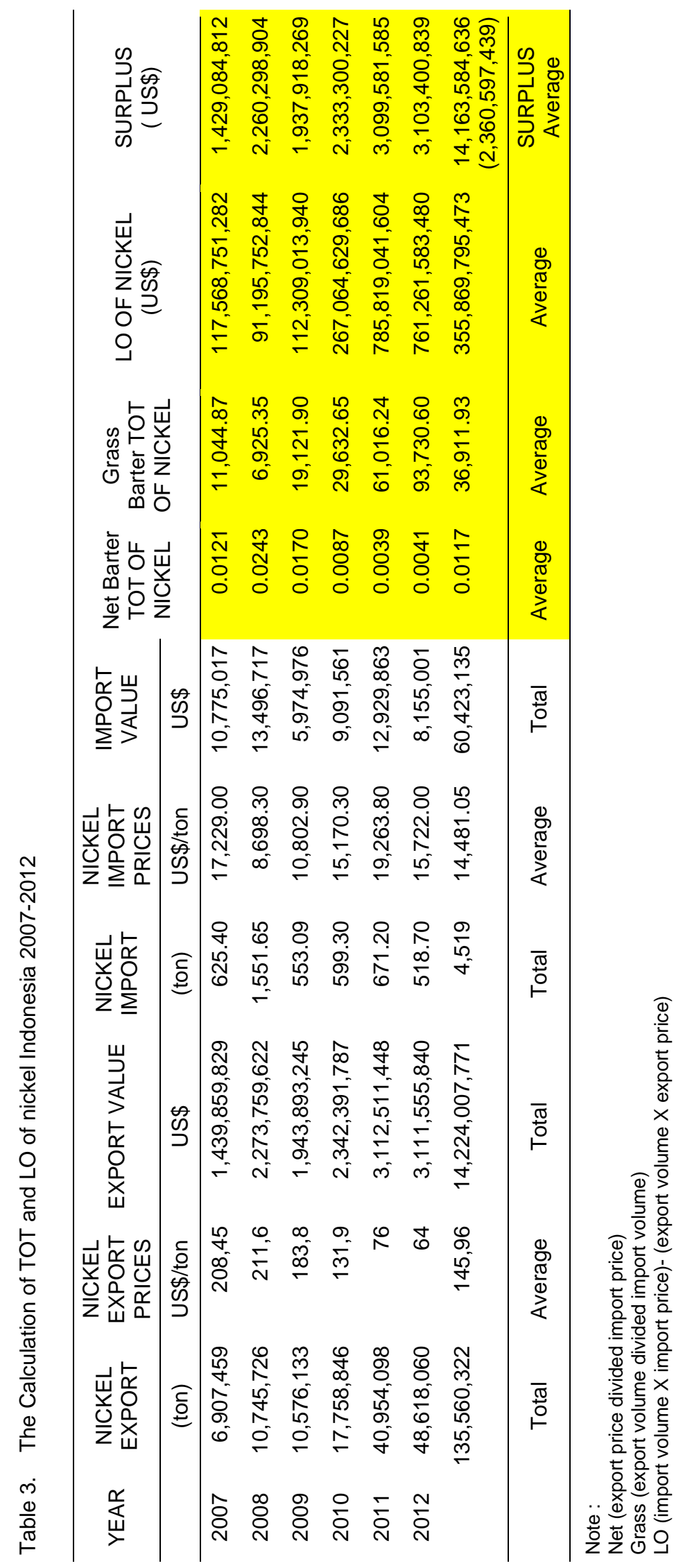


b. The government's policy to increase the value-added carried out by implementing Law No. Regulation No. 4/2009 and Minister of EMR No.1/2014 cannot be postphoned due to nickel resources and reserves will run out at one time and it cannot be renewed.

c. The construction of nickel processing and refining facilities in Indonesia (especially in Southeast Sulawesi) will be implemented immediately, so that next TOT values of nickel $>1$ and the export and import values of nickel are getting positive.'

d. If the nickel processing industry to metallic nickel can be immediately implemented, it would likely be able to increase the national export value of nickel, acquire surplus, increase national revenue, and the TOT level of nickel Indonesia.

e. The existence of the nickel processing industry in the country, it is not only able to increase exports or TOT $>1$, but Indonesia can also participate and role in supplying the needs of the world's nickel metal increase due to rapid development in developing and developed countries which need stainless steel, nickel alloy, batteries and nickel metal. As long as Indonesia only exported nickel ore product, it would be very wise if Indonesia can process it in advance, so it could increase the selling value.

f. The attendant indicators improve TOT trade of nickel indirectly, and it should be implemented, such as: local governments must harmonize with all sorts of local policy to the central government's policy (implementation of Law No. 23/2014 On Local Autonomy) to provide legal certainty for investors in the mining sector, there is no overlapping of WP land, land use, permitting process and the boundaries of the regency, energy support to smelters, incentives to accelerate the construction of the smelter in the form of tax holidays and import duty exemption for capital goods, the industrial area special to build a nickel smelter, roadmap for upstreamdownstream (production chain of national nickel industry) are interwoven with a sturdy, infrastructure support on site and off site smelter, reducing interference of negative stakeholders who can cause great costs production.

g. Considering the nickel resources and reserves are unrenewable natural resources, the government should be consistent and more assertive in overseeing the implementation of Law No. 4/2009 and Minister of EMR Regulation No. 1/2014 of the ValueAdded of nickel, so that Indonesia can export processed products in nickel metal, but no export in raw form of nickel ore. Therefore, Indonesia can export it at high price (many times) of the nickel price itself without having to re-import.

\section{ACKNOWLEDGEMENT}

The author would like to thank the Head of Mining and Energy Department of the Southeast Sulawesi Province and his staff who have provided data and information on the nickel industry. It is very helpful in supporting this study.

\section{REFERENCES}

Amir, M.S., 2004. Seluk beluk dan teknik perdagangan luar negeri, Jakarta. $389 \mathrm{~h}$.

Antoni, 2008. Investasi Langsung Asing (FDI) Dan Perdagangan: Bukti Empiris Di Indonesia. Jurnal Ekonomi Bisnis dan Koperasi, vol. 10, no.2, h. 73-87.

Badan Pusat Statistik, 2014a. Statistik Impor 2007-2014, Jakarta. 143 h.

Badan Pusat Statistik, 2014b. Statistik Ekspor 2007-2014, Jakarta. 209 h.

Badan Pusat Statistik, 2014c. Statistik Industri Besar dan Sedang 2007-2014, Jakarta. $522 \mathrm{~h}$.

Bank Indonesia, 2013. Laporan Bank Indonesia ke Dewan Perwakilan Rakyat Indonesia Kuartal II Tahun 2013, Jakarta.

Batubara, D.M.H., 2015. Analisis Hubungan Ekspor, Impor, PDB dan Utang Luar Negeri Indonesia. Jurnal Ekonomi Kuantitatif Terapan, vol. 8, no.1, h. 4762. 
Directorate General of Mineral and Coal, 2014a. Statistic of potency and balance of mineral and coal resources. Jakarta, 97 p.

Directorate General of Mineral and Coal, 2014b. Indonesia's mineral, coal, geothermal and groundwater statistic, Jakarta. 129 p.

Geological Resource Centre, 2013. Resource and reserve of mineral and coal in Indonesia. Bandung, $192 \mathrm{p}$.

Hanna, S., 2012. Hubungan Perkembangan Ekspor, Impor, dan Regulasi yang Mendasarinya. Buletin IImiah Litbang Perdagangan, vol. 6, no.1, h. 47-64.

Khan, M., Zakir and Hossain, M.I., 2012. A model of bilateral trade balace. Extention and empirical tests. Economic Analysis and Policy, 43(3), p. 377-391.

Kementerian Perdagangan, 2014. Perdagangan ekspor dan impor Indonesia, Pusat Data dan Informasi Kementerian Perdagangan, Jakarta. $203 \mathrm{~h}$.

Kennedy, O., 2013. Kenya's International trade balance an emperical investigation. European Scientific Journal, vol.9 (19), p. 176-189.

Khan, M., Zakir dan Hossain, M.I., 2012. A model of bilateral trade balace. Extention and empirical tests. Economic Analysis and Policy, 403(3), p. 377-391.

Krugman, P., Obstfelt, M., and Melitz, M., 2008. International economics: theory and policy, the $8^{\text {th }}$ Pearson International Edition, $712 \mathrm{p}$.

Ministry of Finance, 2014. Note of Finance and Budget 2014, Jakarta.

Ministry of Industry, 2013. Keynote address of Minister. Forum on Export of Manufacturing Industry, Jakarta.
Poerwadarminta.W.J.S., 2013. Kamus Umum Bahasa Indonesia. Penerbit Balai Pustaka, Jakarta $1.371 \mathrm{~h}$.

Pujoalwanto, B., 2014. Perekonomian Indonesia, Tinjauan Historis, Teoritis dan Empiris. Graha IImu, Jakarta. 266 halaman.

Pramudita, R.S., 2012. Analisis Pengaruh Keterbukaan Perdagangan terhadap Pertumbuhan Ekonomi, Penanaman Modal Asing, dan Tenaga Kerja Industri Besar dan Sedang dengan Pendekatan Vector Autoregessive (Skripsi). Jakarta: Sekolah Tinggi Ilmu Statistik, 156 h.

Prasetyawati, M.D., 2012. Kajian Hutang Pemerintah Indonesia: Keterkaitannya terhadap Perekonomian dan Faktorfaktor yang Memengaruhi Debt Ratio Pemerintah Periode Triwulan III 1998Triwulan III 2011 (Skripsi). Jakarta: Sekolah Tinggi IImu Statistik, 147 h.

Ratya A. and Michael R., 2009. Bisnis dan perdagangan internasional, Jakarta, 196 $\mathrm{h}$.

Safitriani, S., 2014. Perdagangan Internasional dan Foreign Direct Invesment di Indonesia. Buletin Ilmiah Litbang Perdagangan, vol. 8, no.1, h. 94-118.

Southeast Sulawesi Mining Office, 2013. Mining in Southeast Sulawesi, Kendari, $97 \mathrm{p}$.

Sugiarto dan Herlambang, T., 2006. Ekonomi Makro Teori, Analisis dan Kebijakan Dalam Bisnis Manajemen dan Keuangan. Gramedia, Jakarta. 296 h.

Tulus, T., dan Simon, K., 2004. Perdagangan internasional dan neraca pembayaran, teori dan temuan empiris. LP3ES Jakarta. $217 \mathrm{~h}$.

Yuliadi, I., 2008. Analisis Impor Indonesia: Pendekatan Persamaan Simultan. Jurnal Ekonomi dan Studi Pembangunan, vol. 9, no.1, h. 89-104. 